\title{
The Role of High Involvement Management in Reducing the Organizational Cynicism of Faculty Members and Their Assistants at the Faculty of Physical Education for Girls - Helwan University in View of the Quality and Accreditation
}

\author{
Dena Hefny Abd Al Aziz Mamon ${ }^{1}$ \\ ${ }^{1}$ Assistant Professor, Department of Sports Management and Recreation - Faculty of Physical Education for girls - Helwan \\ University
}

\begin{abstract}
The objective of the research is to study the role of management in high containment in reducing organizational cynicism among faculty members and their assistants in the Faculty of Physical Education for Girls - Helwan University in light of quality and accreditation, The researcher used the descriptive approach in the method of case study due to its relevance to the subject of the research, The study sample consisted of (131) members of the teaching staff and members of the supporting body with a percentage of (58.48\%) of the total size of the community, 109 members of the teaching staff and 22 members of the supporting body and Conclusions The value of the arithmetic average of the sample responses on the management scale by high containment at the Faculty of Physical Education for Girls - Helwan University in light of the quality and accreditation (from the point of view of the members of the Taris and their assistants) as a whole with a medium
\end{abstract}

-Research problem and importance:

$\mathrm{O}$ rganizations in the modern era are interested in different types of search for ways and means to make organizational performance more flexible and adaptable and able to achieve competition in various fields. The modern trend in management is not recognition of the workers as a productive force only, but recognition as human beings in the first place they have the right to have conditions And working conditions that allow them to develop their skills and abilities, and this means switching from just doing the required work as required to creativity, innovation, development and self-realization.

The various forms and forms of management are characterized by high containment, ranging from formal participation in decision-making, improving the quality of work life, sharing benefits, designing self-managed teams, owning stockholders, and developing interaction between the organization and employees through participation, development and motivation. These policies and practices seek to manage and empower employees to achieve A high level of harmony between employees and their work environment in a way that ensures their growth, commitment and cooperation to achieve the competitive advantage of the organization. (Nawal Nasr - 2017)

Therefore, the management's approach to high containment enables managers to face increasing competition streams. They help to maintain and sustain human resource development and achieve long-term competitive advantage. Management has now considered high quality to be an important part of the culture of many organizations worldwide. (Wood, S., et.al.-2012)

The Department represents the highest level of cooperation and integration between management and employees, which is the most effective way for the management to find an organization in which the employees feel that they are responsible for them through their inclusion and involvement in the work of the organization and its success and returns. (Sana Mustafa2016(

On the other hand, Organizational Cynicism is one of the most prevalent negative phenomena in the various organizations. In the United States, more than $40 \%$ of American workers suffer from systematic scorn towards 
their organizations, claiming that they are treated in a manner that is not justice.

Organizational organization is a negative trend that employees have towards their organizations. It consists of three main dimensions (cognitive-emotional-behavioral) and is a response to a long history of personal experiences and experiences in the work environment. (Abdel Hakim Ahmed, Islam on - 2016)

The organizational cynicism consists of three elements: the individual's belief that the organization in which he works lacks the values of transparency and credibility, the negative emotions towards the organization, its leadership and its employees, and the tendency to disregard the expression and public criticism of these negative feelings towards the organization in various forms (Ammar Fathy2015)

The Faculty of Physical Education for Girls - Helwan University is one of the faculties of Physical Education for Girls (19) in 17 universities. The College has obtained academic accreditation from the National Authority for Quality Assurance of Education and Accreditation by Decision No. 129 dated 26/6/2014. (2018), and the attempt to obtain and maintain the first accreditation and seek the second accreditation work and continuous effort of all members of the faculty and their assistants in the faculty in various aspects of academic and administrative work, was done in the absence of Sharp credit and financial resources crisis The researcher is a member of the quality team who contributed to obtaining the first accreditation and seeking to obtain the second accreditation, and through doing many tasks as Chairman of the complaints committee and executive member of the standard organizational structure, and the standard programs and decisions And the criterion of strategic planning and the internal audit committee, the researcher noted the extent to which the members of the faculty and their staff feel the negative feelings towards the work of quality and requirements, especially as all their expectations and aspirations that the working conditions in college will change positively after the Adoption became unrealistic, where they formed the conviction that it does not have any return on the total return (potential, financial resources, .....) or faculty members (material - entities) as a result of obtaining accreditation.

Hence, in light of what the researcher noted in terms of its role in quality assurance unit of the behaviors and acts of sarcastic faculty members in the faculty, which helps with the completion of the work and quality activities in the required aspect and in the light of what has been confirmed by many studies on the negative effects of the phenomenon of organizational cynicism on various fields (2016), Islam on (2016), Click (KILIÇ, R, - 2015), KESEN, M. \& AKYÜZ, B., - 2016), Sanobar, N. \& Bajestani, M., - 2015) and others.

Which calls on the academic leaders to contain the faculty members by focusing on the essence of management by containing the high level of trust between them and in addition to enabling them to develop their knowledge and skills through continuous training in the framework of collective work, Encourage cooperation and achievement of tasks and intensive training and diverse, and their participation information and decision-making workers can trust the decisions taken in the taking, and many of the previous studies on the positive role of the Department of high containment on the quality of work (2016), Jayanthi Anobama (Jayanthi, V., \& Anupama, R.-2016), Yang and Min (Ying Z. \& Min Z., - 2016).

Hence the idea of the current study in an attempt to identify the role of the administration as a high administrative intervention that offers positive opportunities to maximize the human potential of faculty members by ensuring their development, participation and training in reducing organizational cynicism as one of the negative manifestations of the recent widespread, In light of the high burdens and requirements imposed by quality and accreditation.

\section{- Research Objective: -}

The objective of the research is to study the role of management in high containment in reducing organizational cynicism among faculty members and their assistants in the Faculty of Physical Education for Girls Helwan University in light of quality and accreditation by identifying:

1 - the degree of high containment management Faculty of Physical Education for Girls - Helwan University in light of quality and accreditation.

2 - Differences in the degree of management in high containment Faculty of Physical Education for Girls Helwan University in light of quality and accreditation according to the variable functional grade (Professor Assistant Professor - Teacher - Assistant Lecturer Teaching Assistant).

3 - Degree of organizational cynicism among faculty members and their assistants at the Faculty of Physical Education for Girls - Helwan University in light of quality and accreditation. 
4 - Differences in the degree of organizational cynicism among faculty members and their assistants at the Faculty of Physical Education for Girls - Helwan University in view of the quality and accreditation according to the variable of functional grade (Professor - Assistant Professor - Teacher - Assistant Lecturer - Teaching Assistant).

5 - The relationship between management with high containment and organizational cynicism among faculty members and their assistants in the Faculty of Physical Education for Girls - Helwan University in light of quality and accreditation.

6 - The percentage of the Department of high containment in the organizational cynicism of faculty members and their assistants in the Faculty of Physical Education for Girls - Helwan University in light of quality and accreditation.

\section{- Research questions:}

\section{The research answers the following questions:}

1- What is the degree of high containment management at the Faculty of Physical Education for Girls - Helwan University in light of quality and accreditation?

2 - What are the differences in the degree of management in high containment Faculty of Physical Education for Girls - Helwan University in view of the quality and accreditation according to the variable functional grade (Professor - Assistant Professor - Teacher - Assistant teacher - teacher)?

3 - What is the degree of organizational cynicism among faculty members and their assistants at the Faculty of Physical Education for Girls - Helwan University in light of quality and accreditation?

4 - What are the differences in the degree of organizational cynicism among faculty members and their assistants in the Faculty of Physical Education for Girls - Helwan University in view of the quality and accreditation according to the variable of functional grade (Professor Assistant Professor - Teacher - Assistant Lecturer Teacher)?
5- What is the relationship between management with high containment and organizational cynicism among faculty members and their assistants at the Faculty of Physical Education for Girls - Helwan University in light of quality and accreditation?

6 - What is the percentage of the administration's high containment in the organizational cynicism of faculty members and their assistants at the Faculty of Physical Education for Girls - Helwan University in light of quality and accreditation?

\section{- Search procedures:}

\section{- Methodology used:}

The researcher used the descriptive approach in the method of case study due to its relevance to the subject of the research.

\section{- The research sample:}

The study sample consisted of (131) members of the teaching staff and members of the supporting body with a percentage of $(58.48 \%)$ of the total size of the community, 109 members of the teaching staff and 22 members of the supporting body

\section{- Data collection tools: -}

The researcher used the following tools to collect the study data:

First: the measure of management of high containment at the Faculty of Physical Education for Girls - Helwan University in light of quality standards and accreditation (from the point of view of the members of the staff and their assistants), (designed by the researcher).

Second: the measure of organizational cynicism among faculty members at the Faculty of Physical Education for Girls - Helwan University in light of the quality and accreditation standards (from their point of view), (designed by the researcher).

\section{- Presentation and discussion of the results:}

\section{- First: Displaying the results: -}


Table (1)

The arithmetical mean, standard deviation, and torsion factor of the sample responses on the dimensions of the management measure by high containment at the Faculty of Physical Education for Girls, Helwan University in light of quality and accreditation ( $N=93$ )

\begin{tabular}{|c|c|c|c|c|}
\hline $\mathbf{S}$ & Dimensions & $\mathbf{M}$ & $\mathbf{E}$ & $\mathbf{L}$ \\
\hline 1 & First dimension: Participation in making decisions & 29.88 & 3.33 & 633.- \\
\hline 2 & Second dimension: Training & 22.50 & 3.05 & 422.- \\
\hline 3 & Third Dimension: Sharing knowledge & 31.98 & 4.15 & 1.16 \\
\hline 4 & Fourth Dimension: Technological Support & 31.50 & 4.11 & 451. - \\
\hline \multicolumn{2}{|r|}{ Total degree } & & 115.86 & 11.16 \\
\hline
\end{tabular}

Table (1) shows the following:

- The spindle coefficient of the sample responses is limited to the dimensions of the scale between $(+3,-3)$ indicating the moderation of the data.

- The values of the arithmetic averages of the sample responses were limited to the dimensions of the management scale by the high containment of the Faculty of Physical Education for Girls - Helwan University in view of the quality and accreditation (from the point of view of the members of the staff and their assistants)

Between (22.50) for the second dimension, and (31.50) for the third dimension.
- The value of the arithmetical mean of the sample responses on the management scale by high containment at the Faculty of Physical Education for Girls - Helwan University in light of the quality and accreditation (from the point of view of the members of the Taris and their assistants) as a whole with a medium level of (115.86).

- The dimensions of the management scale in high containment of the Faculty of Physical Education for Girls - Helwan University in light of the quality and accreditation (from the point of view of the members of the Board of Trustees and their assistants) are arranged in descending order according to the value of the arithmetical mean as follows (knowledge sharing - technological support.

Table (2)

Analysis of variance of the responses of the sample on the dimensions of the management scale by high containment at the Faculty of Physical Education for Girls - Helwan University in view of the quality and accreditation (from the point of view of the members of the Board of Trustees and their assistants) According to the functional grade $(\mathrm{N}=93)$

\begin{tabular}{|c|c|c|c|c|c|c|}
\hline Dimensions & Source of Contrast & Squares total & DH & Squares averages & $\mathbf{F}$ & Indicate \\
\hline \multirow{2}{*}{ First dimension: Participation in making decisions } & Between groups & 1463.58 & 4 & 365.89 & \multirow[t]{2}{*}{$22.72 *$} & \multirow[t]{2}{*}{0.00} \\
\hline & Within groups & 1417.14 & 88 & 16.10 & & \\
\hline \multirow{2}{*}{ Second dimension: Training } & Between groups & 967.35 & 4 & 241.84 & \multirow[t]{2}{*}{$17.40^{*}$} & \multirow[t]{2}{*}{0.00} \\
\hline & Within groups & 1223.09 & 88 & 13.89 & & \\
\hline \multirow{2}{*}{ Third Dimension: Sharing knowledge } & Between groups & 1703.69 & 4 & 425.92 & \multirow[t]{2}{*}{$19.61 *$} & \multirow[t]{2}{*}{0.00} \\
\hline & Within groups & 1910.56 & 88 & 21.71 & & \\
\hline \multirow{2}{*}{ Fourth Dimension: Technological Support } & Between groups & 1783.46 & 4 & 445.86 & \multirow[t]{2}{*}{$19.26^{*}$} & \multirow[t]{2}{*}{0.00} \\
\hline & Within groups & 2036.35 & 88 & 23.14 & & \\
\hline \multirow{2}{*}{ Total degree } & Between groups & 23111.20 & 4 & 5777.80 & \multirow{2}{*}{$41.41^{*}$} & \multirow{2}{*}{0.00} \\
\hline & Within groups & 12275.69 & 88 & 139.49 & & \\
\hline
\end{tabular}

* Significance $<(05$.

It is clear from Table (2) that there are statistically significant differences between the responses of the faculty members and their assistants on the dimensions of the management scale by the high containment of the
Faculty of Physical Education for Girls - Helwan University in view of the quality and accreditation (from the point of view of the members of the staff and their assistants) Moral LSD Table 21 illustrates this. 
Table (3)

The significance of the differences of the responses of the sample on the dimensions of the management scale by high containment at the Faculty of Physical Education for Girls - Helwan University in light of the quality and accreditation (from the point of view of the members of the Board of Trustees and their assistants) According to the functional grade $(\mathrm{N}=93)$

\begin{tabular}{|c|c|c|c|c|c|c|c|}
\hline Dimensions & Job rank & $\begin{array}{c}\text { Arithmetic } \\
\text { av. }\end{array}$ & Pro & Ass. Pro & Lecturer & $\begin{array}{c}\text { Ass. } \\
\text { Lecturer }\end{array}$ & $\begin{array}{l}\text { Teaching } \\
\text { Assistant }\end{array}$ \\
\hline \multirow{5}{*}{$\begin{array}{l}\text { First dimension } \\
\text { Participation in } \\
\text { making decisions }\end{array}$} & Pro. & 37.80 & - & $3.0 *$ & 1.95 & 5.35 & $18.00 *$ \\
\hline & Ass. Pro. & 34.80 & - & - & $1.04-$ & 2.35 & $15.00^{*}$ \\
\hline & Lecturer & 35.84 & - & - & - & $3.39 *$ & $16.04^{*}$ \\
\hline & Ass. Lecturer & 32.44 & - & - & - & - & $12.64^{*}$ \\
\hline & Teaching Assistant & 19.80 & - & - & - & - & - \\
\hline \multirow{5}{*}{$\begin{array}{l}\text { Second } \\
\text { dimension: } \\
\text { Training }\end{array}$} & Pro. & 34.13 & - & $2.33^{*}$ & 1.60 & 4.02 & $14.73^{*}$ \\
\hline & Ass. Pro. & 31.80 & - & - & 726. & 1.68 & $12.40^{*}$ \\
\hline & Lecturer & 32.52 & - & - & - & 2.41 & $13.12^{*}$ \\
\hline & Ass. Lecturer & 30.11 & - & - & - & - & $10.71^{*}$ \\
\hline & Teaching Assistant & 19.40 & - & - & - & - & - \\
\hline \multirow{5}{*}{$\begin{array}{l}\text { Third Dimension: } \\
\text { Sharing } \\
\text { knowledge }\end{array}$} & Pro. & 40.43 & - & $4.36^{*}$ & $3.59^{*}$ & $4.76^{*}$ & $19.63^{*}$ \\
\hline & Ass. Pro. & 36.06 & - & - & 775.- & 400. & $15.26^{*}$ \\
\hline & Lecturer & 36.84 & - & - & - & 1.17 & $16.04^{*}$ \\
\hline & Ass. Lecturer & 35.66 & - & - & - & - & $14.86^{*}$ \\
\hline & Teaching Assistant & 20.80 & - & - & - & - & - \\
\hline \multirow{5}{*}{$\begin{array}{c}\text { Fourth } \\
\text { Dimension: } \\
\text { Technological } \\
\text { Support }\end{array}$} & Pro. & 39.83 & - & $3.73^{*}$ & 2.35 & $7.61^{*}$ & $19.23^{*}$ \\
\hline & Ass. Pro. & 36.10 & - & - & $1.37-$ & $3.87 *$ & $15.50^{*}$ \\
\hline & Lecturer & 37.47 & - & - & - & $5.25^{*}$ & $16.87^{*}$ \\
\hline & Ass. Lecturer & 32.22 & - & - & - & - & $11.62 *$ \\
\hline & Teaching Assistant & 20.60 & - & - & - & - & - \\
\hline \multirow{5}{*}{ Total degree } & Pro. & 152.20 & - & $13.43^{*}$ & $9.51^{*}$ & $21.75^{*}$ & $71.60^{*}$ \\
\hline & Ass. Pro. & 138.76 & - & - & $3.91-$ & 8.32 & $58.16^{*}$ \\
\hline & Lecturer & 142.68 & - & - & - & $12.23^{*}$ & $62.08^{*}$ \\
\hline & Ass. Lecturer & 130.44 & - & - & - & - & $49.48^{*}$ \\
\hline & Teaching Assistant & 80.60 & - & - & - & - & - \\
\hline
\end{tabular}

- Table (3) shows the following:

- There are significant differences between the professor and both (Assistant Professor - Teacher - Assistant teacher - teacher) in the overall score of their response on the management scale of high containment Faculty of Physical Education for Girls - Helwan University in light of quality and accreditation (from the point of view of the members of the Board and their assistants), In favor of Professor.

- There are statistically significant differences between the assistant professor and the student in the total score of their response on the management scale by high containment at the Faculty of Physical Education for Girls - Helwan University in view of the quality and accreditation (from the point of view of the members of the staff and their assistants).
- There are differences of statistical significance between the teacher and the (assistant teacher - the teacher) in the overall score of their response on the management scale of high containment at the Faculty of Physical Education for Girls - Helwan University in light of the quality and accreditation (from the point of view of the members of the staff and their assistants) .

- There are statistically significant differences between the assistant teacher and the teacher in the total score of their response on the management scale of high containment at the Faculty of Physical Education for Girls - Helwan University in light of the quality and accreditation (from the point of view of the members of the faculty and their assistants). 
Table (4)

The arithmetical mean, the standard deviation, and the torsion coefficient of the sample responses on the dimensions of the organizational sarcasm scale among faculty members and their assistants at the Faculty of Physical Education for Girls Helwan University in light of Quality and Accreditation (from their point of view) $(\mathbf{N}=93$ )

\begin{tabular}{|c|c|c|c|c|}
\hline s & Dimensions & $\mathbf{M}$ & $\mathbf{E}$ & $\mathbf{L}$ \\
\hline 1 & The first dimension: cognitive cynicism & 43.88 & 2.87 & 254.- \\
\hline 2 & Second dimension: emotional cynicism & 50.01 & 3.90 & 178. \\
\hline 3 & Third dimension: behavioral cynicism & 42.77 & 3.11 & 157. \\
\hline & Total score & & 136.66 & 5.98 \\
\hline
\end{tabular}

Table (4) shows the following:

- The spindle coefficient of the sample responses is limited to the dimensions of the scale between $(+3,-3)$ indicating the moderation of the data.

- The values of the arithmetical averages of the sample responses were limited to the organizational scam of faculty members and their assistants at the Faculty of Physical Education for Girls - Helwan University in light of the quality and accreditation (from their point of view) between (42.77) for the third dimension and (50.01) for the second dimension.
The value of the arithmetical mean of the sample responses on the scale of the organizational cynicism scale among faculty members and their assistants at the Faculty of Physical Education for Girls - Helwan University in light of the quality and accreditation (in their view) as a whole was higher than the average (136.66).

- The dimensions of the measure of organizational cynicism among faculty members and their assistants in the Faculty of Physical Education for Girls - Helwan University in view of the quality and accreditation (from their point of view) ranked descending according to the value of the arithmetic average as follows (emotional scorn - cognitive scorn - behavioral cynicism).

Table (5)

Analysis of variance of the sample responses on the dimensions of the scale of organizational cynicism among faculty members and their assistants at the Faculty of Physical Education for Girls - Helwan University in view of the quality and accreditation (from their point of view) According to the functional grade $(\mathbf{n}=93)$

\begin{tabular}{|c|c|c|c|c|c|c|}
\hline Dimensions & Varity source & Total squares & D H & Average of squares & $\mathbf{F}$ & Index \\
\hline \multirow{2}{*}{ The first dimension: cognitive cynicism } & Between groups & 3428.48 & 4 & 857.12 & \multirow[t]{2}{*}{$38.57^{*}$} & \multirow[t]{2}{*}{0.00} \\
\hline & Within groups & 1955.58 & 88 & 22.22 & & \\
\hline \multirow{2}{*}{ Second dimension: emotional cynicism } & Between groups & 4759.81 & 4 & 1189.95 & \multirow[t]{2}{*}{$64.79^{*}$} & \multirow[t]{2}{*}{0.00} \\
\hline & Within groups & 1616.01 & 88 & 18.36 & & \\
\hline \multirow{2}{*}{ Third dimension: behavioral cynicism } & Between groups & 2996.68 & 4 & 749.17 & \multirow[t]{2}{*}{$47.03^{*}$} & \multirow[t]{2}{*}{0.00} \\
\hline & Within groups & 1401.57 & 88 & 15.92 & & \\
\hline \multirow{2}{*}{ Total score } & Between groups & 32968.05 & 4 & 8242.01 & \multirow{2}{*}{$135.04 *$} & \multirow{2}{*}{0.00} \\
\hline & Within groups & 5370.74 & 88 & 61.03 & & \\
\hline
\end{tabular}

* Significance $<(05$.

It is clear from Table (5) that there are statistically significant differences between the responses of the faculty members and their assistants on the dimensions of the scale of the organizational cynicism scale among the faculty members and their assistants in the Faculty of
Physical Education for Girls - Helwan University in view of the quality and accreditation (from their point of view). The least significant difference is LSD Table (6) illustrates this. 
Table (6)

The significance of the differences of the sample responses on the dimensions of the measure of organizational cynicism among faculty members and their assistants at the Faculty of Physical Education for Girls - Helwan University in view of the quality and accreditation (from their point of view) According to the functional grade $(\mathrm{N}=93$ )

\begin{tabular}{|c|c|c|c|c|c|c|c|}
\hline Dimensions & Job rank & $\begin{array}{l}\text { Arithmetic } \\
\text { av. }\end{array}$ & Pro & Ass. Pro & Lecturer & Ass. Lecturer & $\begin{array}{l}\text { Teaching } \\
\text { Assistant }\end{array}$ \\
\hline \multirow{5}{*}{$\begin{array}{l}\text { The first dimension: } \\
\text { cognitive cynicism }\end{array}$} & Pro. & 38.00 & - & $*-11.70$ & $*-12.84$ & $*_{-13.22}$ & $*_{-17.40}$ \\
\hline & Ass. Pro. & 49.70 & - & - & -1.14 & -1.52 & $*_{-5.70}$ \\
\hline & Lecturer & 50.84 & - & - & - & -.380 & -4.55 \\
\hline & Ass. Lecturer & 51.22 & - & - & - & - & -4.17 \\
\hline & $\begin{array}{l}\text { Teaching } \\
\text { Assistant }\end{array}$ & 55.40 & - & - & - & - & - \\
\hline \multirow{5}{*}{$\begin{array}{l}\text { Second dimension: } \\
\text { emotional cynicism }\end{array}$} & Pro. & 39.03 & - & $*-14.80$ & $*-15.22$ & $*-16.30$ & $*-16.36$ \\
\hline & Ass. Pro. & 53.83 & - & - & -.429 & -1.50 & -1.56 \\
\hline & Lecturer & 54.26 & - & - & - & -1.07 & -1.13 \\
\hline & Ass. Lecturer & 55.33 & - & - & - & - & -.066 \\
\hline & $\begin{array}{l}\text { Teaching } \\
\text { Assistant }\end{array}$ & 55.40 & - & - & - & - & - \\
\hline \multirow{5}{*}{$\begin{array}{l}\text { Third dimension: } \\
\text { behavioral cynicism }\end{array}$} & Pro. & 38.80 & - & $*_{-10.73}$ & $*_{-}-11.83$ & $*_{-1}-12.08$ & $*_{-17.20}$ \\
\hline & Ass. Pro. & 49.53 & - & - & -1.09 & -1.35 & $*-6.46$ \\
\hline & Lecturer & 50.63 & - & - & - & -.257 & $*-5.36$ \\
\hline & Ass. Lecturer & 50.88 & - & - & - & - & $*_{-5.11}$ \\
\hline & $\begin{array}{l}\text { Teaching } \\
\text { Assistant }\end{array}$ & 56.00 & - & - & - & - & - \\
\hline \multirow{5}{*}{ Total score } & Pro. & 115.83 & - & $*_{-37.23}$ & $*_{-39.09}$ & $*-41.61$ & $*_{-50.96}$ \\
\hline & Ass. Pro. & 153.06 & - & - & -2.67 & -4.37 & $*-13.73$ \\
\hline & Lecturer & 155.73 & - & - & - & -1.70 & $*-11.06$ \\
\hline & Ass. Lecturer & 157.44 & - & - & - & - & *-9.35 \\
\hline & $\begin{array}{l}\text { Teaching } \\
\text { Assistant }\end{array}$ & 166.80 & - & - & - & - & - \\
\hline
\end{tabular}

- Table (6) shows the following:

- There are significant differences between the professor and both (Assistant Professor - Teacher - Assistant Teacher - Teacher) in the overall degree of their responses on the scale of organizational cynicism among faculty members and their assistants in the Faculty of Physical Education for Girls - Helwan University in light of quality and accreditation (from their point of view), In favor of the author.

- There are statistically significant differences between the assistant professor and the teacher in the total degree of their responses on the scale of organizational cynicism among faculty members and their assistants in the Faculty of Physical Education for Girls - Helwan University in light of the quality and accreditation (from their point of view).

- There are significant differences between the teacher and the teacher in the total score of their response on the scale of organizational cynicism among faculty members and their assistants in the Faculty of Physical Education for Girls - Helwan University in view of the quality and accreditation (from their point of view).

- There are statistically significant differences between the assistant teacher and the teacher in the total score of their response on the scale of organizational cynicism among faculty members and their assistants in the Faculty of Physical Education for Girls - Helwan University in view of the quality and accreditation (from their point of view). 
Table (7)

The correlations between the responses of the sample members were based on the dimensions of both the high containment management scale and the systematic scaling index of the total sample $(\mathrm{N}=93)$

\begin{tabular}{|c|c|c|c|c|}
\hline $\begin{array}{c}\text { Organizational cynicism } \\
\text { Management of high containment }\end{array}$ & $\begin{array}{l}\text { The first dimension: } \\
\text { cognitive cynicism }\end{array}$ & $\begin{array}{l}\text { The second dimension: } \\
\text { emotional cynicism }\end{array}$ & $\begin{array}{l}\text { Third dimension: Behavioral } \\
\text { cynicism degree }\end{array}$ & $\begin{array}{r}\text { Total } \\
\text { degree }\end{array}$ \\
\hline $\begin{array}{l}\text { First dimension: Participation in } \\
\text { making and making decisions }\end{array}$ & 339.-* & 438.-* & 421.-* & $44.8-*$ \\
\hline Second dimension: Training & 337.-** & 377.-* & 428.-* & 425.-* \\
\hline Third Dimension: Sharing knowledge & 410.-* & 537.-* & 401.-* & 436.-* \\
\hline Total score & 433-.* & $438 .-*$ & 499.-* & 510.-* \\
\hline
\end{tabular}

* The value (t) of the tabular $=(205$.

Table (7) shows the following:

- The existence of a statistical correlation between the dimensions of the measure of management by high containment in the Faculty of Physical Education for girls and the dimensions of the measure of organizational cynicism among faculty members and their assistants at the Faculty of Physical Education for Girls.
- The existence of a reverse correlation of statistical significance between the total score of the management of high containment in the Faculty of Physical Education for girls and the total score of the measure of organizational cynicism among faculty members and their assistants at the Faculty of Physical Education for Girls.

Table (8)

Contributing variables of management containment in achieving cognitive cynicism

\begin{tabular}{|c|c|c|c|c|c|}
\hline \multirow{2}{*}{ Step } & $\begin{array}{c}\text { Standard } \\
\text { error }\end{array}$ & $\begin{array}{c}\text { Fixes } \\
\text { amount }\end{array}$ & \multirow{2}{*}{ F } & Contribution variables of high containment management & \multirow{2}{*}{ Percentage \% } \\
\cline { 4 - 5 } & 7.01 & 65.03 & 18.42 & Sharing knowledge & $41.0 \%-$ \\
\hline $\mathbf{1}$ & & $501 .-$ & \\
\hline
\end{tabular}

Table (8) shows the following:

- The variables contributing from the management of high containment in the cognitive scorn came in the dimension $\mathrm{Y}=\mathrm{a}+\mathrm{b} 1 \mathrm{x} 1$ (knowledge sharing) and by $(41.0 \%)$ so the following equation can be predicted:

Cognitive Cynicism $=65.03-(501 . \mathrm{x}$ Knowledge Sharing $)$

Table (9)

Contributing variables of management containment in achieving emotional cynicism

\begin{tabular}{|c|c|c|c|c|c|}
\hline \multirow{2}{*}{ Step } & \multirow{2}{*}{$\begin{array}{c}\text { Standard } \\
\text { error }\end{array}$} & \multirow{2}{*}{$\begin{array}{c}\text { Fixes } \\
\text { amount }\end{array}$} & \multirow{2}{*}{$\mathbf{F}$} & Contribution variables of high containment management & \multirow{2}{*}{ Percentage \% } \\
\hline & & & & Participation in decision-making & \\
\hline 1 & 7.52 & 72.13 & 21.57 & $651 .-$ & $43.8 \%$ \\
\hline
\end{tabular}

Table (9) shows the following:

- The variables contributing to the management of high containment in the emotional satire came in after (participation in decision-making) and by (43.8\%) and thus can predict the following equation:
$\mathrm{Y}=\mathrm{a}+\mathrm{b} 1 \mathrm{x} 1$

Emotional cynicism $=72.13-(651 . \times$ Knowledge is shared) 
Table (10)

Contributing variables of management containment in achieving behavioral cynicism

\begin{tabular}{|c|c|c|c|c|c|c|}
\hline \multirow{2}{*}{ Step } & \multirow{2}{*}{$\begin{array}{c}\text { Standard } \\
\text { error }\end{array}$} & \multirow{2}{*}{$\begin{array}{c}\text { Fixes } \\
\text { amount }\end{array}$} & \multirow{2}{*}{ F } & \multicolumn{2}{|c|}{ Contribution variables of high containment management } & Percentage \% \\
\cline { 5 - 7 } & & & Technological support & Training \\
\hline $\mathbf{1}$ & 6.24 & 63.89 & 21.68 & $471 .-$ & - & $43.9 \%$ \\
\hline $\mathbf{2}$ & 6.14 & 68.68 & 13.19 & $298 .-$ & $348 .-$ & $47.6 \%$ \\
\hline
\end{tabular}

Table (10) shows the following:

- The variables contributing from the management of high containment in behavioral cynicism were represented in the dimension of technological support by $43.9 \%$ followed by (training) and by percentage of $47.6 \%$. The following equation can be predicted:
$\mathrm{Y}=\mathrm{a}+\mathrm{b} 1 \mathrm{x} 1+\mathrm{b} 2 \mathrm{x} 2$

Behavioral cynicism $=68.68-(298 . \times$ Technological support) - (348. $\times$ Training)

Table (11)

The percentage of the administration's contribution to high containment in determining the degree of organizational cynicism among the members of the board Teaching and their assistants at the Faculty of Physical Education for Girls - Helwan

University $(\mathbf{N}=\mathbf{9 3})$

\begin{tabular}{|c|c|c|c|c|c|c|}
\hline \multirow[b]{2}{*}{ Step } & \multirow{2}{*}{$\begin{array}{c}\text { Standard } \\
\text { error }\end{array}$} & \multirow{2}{*}{$\begin{array}{c}\text { Fixes } \\
\text { amount }\end{array}$} & \multicolumn{3}{|c|}{ Contribution dimensions and slope coefficients } & \multirow[b]{2}{*}{ Percentage $\%$} \\
\hline & & & $\mathbf{F}$ & $\begin{array}{c}\text { Participation in making } \\
\text { and making decisions }\end{array}$ & Sharing knowledge & \\
\hline 1 & 199.89 & 6.94 & 22.86 & $1.63-$ & - & $44.8 \%$ \\
\hline 2 & 201.94 & 17.99 & 14.19 & $1.05-$ & 828.- & $49 \%$ \\
\hline
\end{tabular}

Table (11) shows:

- There are two variables of management variables high containment is to contribute to the degree of organizational cynicism among faculty members and their assistants in the Faculty of Physical Education for Girls Helwan University, and can be arranged in descending order according to the proportion of their contribution as follows:

- The first variable is participation in making and making decisions with a contribution rate of $(44.8 \%)$.

- The second variable is (knowledge sharing) with a contribution rate of $(4.2 \%)$ to increase the percentage of management by high containment in the effectiveness of the degree of organizational cynicism to (49\%).

- It was also concluded that other dimensions of higher management dimensions (training - technological support) have no impact on the degree of organizational cynicism.

- The following prediction equation can be inferred:

$\mathrm{Y}=\mathrm{a}+\mathrm{b} 1 \mathrm{x} 1+\mathrm{b} 2 \times 2$.

Where: $\mathrm{Y} \rightarrow$ dependent variable (organizational cynicism of faculty members and their assistants).

$: a \rightarrow$ Fixed amount.
: b المتغير Contributing / independent variable (high containment management).

$: \mathrm{x} \rightarrow$ correlation coefficient.

Organizational mockery of faculty members and their assistants $=209.94$ (1.05 x Participation in making and making decisions) - (828. x Knowledge sharing)

\section{- Second: Discussion of the results:}

\section{- Discuss the first question:}

The results of the study in the field of recognition of the degree of management of high containment at the Faculty of Physical Education for Girls - Helwan University in light of the quality and accreditation, as shown in Table (2), showed that the mean of the sample responses on the management scale with high containment as a whole was average (115.86) The dimensions of the management scale can also be arranged by holding the higher high according to the mean of the arithmetic average as follows (knowledge sharing - technological support - participation in decision making - training).

- The researcher believes that the responses of the faculty members and their assistants to the management scale of the high containment as a whole was medium. It is due to the group of management practices aimed at creating positive working relationships between them and the 
faculty members and their assistants by involving them in making decisions, And attention to training operations, and their participation information, and commitment to technological support to work, to achieve the vision and mission of the College and its strategic objectives through:

A - Participation of members of the faculty and their assistants with their opinions, suggestions and recommendations on various technical and organizational issues on which decisions are taken.

B- Organizing courses, seminars and workshops for faculty members and their assistants, which are determined in light of the training needs of them, through the boards of the scientific departments, the quality assurance unit and the training committee in the faculty, in order to acquire knowledge and develop skills and abilities.

C - Work on the rapid circulation of knowledge between the members of the faculty and their assistants, and the various units and committees and sections of scientific and administrative college, the appropriate and appropriate.

D- Work on linking the performance of faculty members and their assistants with the various units, committees and scientific and administrative departments in the college using modern technology.

Thus, the first question has been answered

"What is the degree of management by high containment in the Faculty of Physical Education for Girls - Helwan University in light of quality and accreditation?"

\section{- Discuss the second question:}

- The results of the study in the field of identification of differences in the degree of management by high containment at the Faculty of Physical Education for Girls - Helwan University in light of the quality and accreditation according to the variable of functional grade (Professor - Assistant Professor - Teacher - Assistant Lecturer - Demonstrator) ), That there are differences of statistical significance between the professor and both (assistant professor - teacher - teacher assistant - teacher) in the overall score of their response on the scale of management contain high for the benefit of the professor, and there are differences of statistical significance between the Assistant Professor and the teacher in the total degree of their response On the management scale b And there are significant differences between the teacher and the (assistant teacher - the teacher) in the overall score of their response on the management measure of high containment for the benefit of the teacher. There are also significant differences between the assistant teacher and the teacher in The total score of their response on the management scale by high containment is in favor of the assistant teacher.

The results of the present study are consistent with the findings of Jayanthi, V., \& Anupama, R.-2016, where they concluded that high containment management provides staff with the power and skills to make and effectively implement decisions, Functional class .

The findings of the present study are in line with the results of the Ying Z. \& Min Z, 2016 study, where they concluded that the functional participation provided by the Department with high containment has had a positive effect on participation in planning, problem solving and horizontal communication. Appear clearly at higher grades.

- The researcher believes that the existence of differences of statistical significance between the professor and both (assistant professor - teacher - teacher assistant - teacher) in the overall degree of their response on the scale of management contain high for the benefit of the professor, but due to the nature of the tasks and powers granted to the category of professor, Functional to the other and less whenever the degree of functional such as:

- The professor category is one of the most important groups participating in the boards of committees of the college (the Higher Studies Committee - the Committee for Education and Students ............), which allows them to participate more in many matters and decisions that are made Take it.

- The professor category is one of the most involved in the teaching of postgraduate courses in most departments of the college (diploma stage - master stage - doctoral stage), which allows them to identify more problems and contribute to their presentation to the decision makers as well as contributing to solving them. To obtain greater material and moral incentives that are not received by the lower categories.

- The professor category is one of the most involved in supervising the scientific messages in most departments of the faculty (Master-PhD), which allows them to better identify the many problems and contribute to the presentation to the decision-makers as well as contributing to solve them, in addition to obtaining a greater degree of The material and moral incentives that the lower categories do not receive.

- The professor category is one of the most categories that are headed by many units and committees established by the College Assurance Unit or affiliated to the agents or 
scientific departments, which gives them many opportunities to participate in making many decisions which makes them feel effective and influential in the college community.

\section{Thus, the second question has been answered}

"What are the differences in the degree of management in high containment in the Faculty of Physical Education for Girls - Helwan University in view of the quality and accreditation according to the variable functional grade (Professor - Assistant Professor - Teacher - Assistant teacher - teacher)?"

\section{- Discussion of the third question: -}

- The results of the study in the field of recognition of the degree of organizational cynicism among faculty members and their assistants in the Faculty of Physical Education for Girls - Helwan University in light of quality and accreditation, as shown in tables (5), where

The mean value of the sample responses on the scale of the organizational scaling index as a whole was higher than the average (136.66)., And it was possible to arrange the dimensions of the scale of organizational cynicism among faculty members and their assistants in the Faculty of Physical Education for girls ranked descending according to the value of the arithmetic average as follows (emotional scorn - cognitive scorn - behavioral cynicism).

The results of the present study are consistent with the results of the Hamid Salem study (2017), where the dimensions of organizational cynicism can be arranged according to the value of the mathematical averages in descending order as follows (emotional scorn - cognitive scorn - behavioral scorn).

The findings of the present study are consistent with the results of the Jaling, X, and 2016 study

Coordination staff working for an international logistics company had a high level of organizational cynicism compared to their counterparts in other jobs.

The results of the present study are consistent with the results of the study of Islam and others (Aslam, U., et.al.2016), which concluded that the Pakistani government, public administrations, labor unions and sectoral organizations must work to reduce the degree of organizational cynicism of their organizations In involving staff in decision-making, and building trust between employees and leaders of change.

- The results of the present study also agree with the results of the study of Islam on (2016), where it was found that the dimensions of organizational cynicism can be arranged according to the value of the arithmetical averages, where after the emotional satire came in the first order followed by the cognitive sarcasm in the second order.

- The results of the current study differ with the results of the study of telephone charter and others (2017) where they found that after the behavioral scorn came in the first ranking while the emotional satire came in the last arrangement.

(BALAY, R., et.al.-2013). The results of the present study also differ from the results of the study of both Palae and others

Where they found that the organizational cynicism came to a moderate degree among teachers working in the Sanliurfa Center, and there is a statistically significant positive relationship between organizational cynicism and organizational culture.

- The researcher believes that obtaining the study sample from the members of the teaching staff and their assistants to higher than average degrees in the organizational cynicism but due to several reasons, including:

- The negative attitude of faculty members and their assistants towards the administration of the college and its employees, which is characterized by a great deal of anger, frustration, hopelessness and despair due to the many negative experiences associated with the change efforts because their expectations do not match the actual results of the work.

- The belief of the faculty members and their assistants that the college's work policies lack the principles of justice, equality, transparency and credibility, and that such principles are sacrificed in order to achieve the organizational benefits of the college. This belief is formed by recognizing the contradictions, observations and analysis of the different work experiences of the faculty.

- As the researcher believes that after the emotional satire in the first order for the responses of the sample on the dimensions of the scale of emotional satire, but that most of the sample members of the study members of the faculty and their assistants:

- feel pessimistic when talking about the future of college work, and feel bored of the initiatives of the College seeking to obtain accreditation.

- They are nervous about the many requirements of the quality assurance unit from the scientific departments, and 
are hesitant when asked to give a view on the performance of the faculty leaders.

- They are annoyed when talking about the fairness of the distribution of the scientific burden in the scientific department, and are tired of talking about the importance of applying quality standards in professional work.

Thus, the third question has been answered

"What is the degree of organizational cynicism among faculty members and their assistants at the Faculty of Physical Education for Girls - Helwan University in light of quality and accreditation?"

\section{- Discussion of the fourth question: -}

- The results of the study in the field of identification of differences in the degree of organizational cynicism among faculty members and their assistants at the Faculty of Physical Education for Girls - Helwan University in light of the quality and accreditation according to the variable of functional grade (Professor - Assistant Professor - Teacher - Assistant Lecturer - $(6,7)$, that there are significant differences between the professor and both (assistant professor - teacher - teacher assistant - teacher) in the overall degree of their responses on the scale of organizational cynicism of faculty members and their assistants in favor of the teacher, where there are differences of statistical significance Between the assistant professor and the teacher And there are significant differences between the teacher and the teacher in the total score of their response on the scale of organizational cynicism in favor of the teacher. There are also significant differences between the assistant teacher and the teacher in the total degree To respond to the scale of organizational cynicism in favor of the author.

The results of the present study are consistent with the results of the study of Islam on 2016. The most important results are that there are statistically significant differences between the opinions of the respondents according to the degree of function and gender. The results showed that the level of organizational cynicism is low compared to the members of the supporting body, And there was a convergence in the degree of organizational cynicism between male and female.

The findings of the present study differ from the findings of Scott and K. Zweig (D, 2016), where he concluded that organizational cynicism affects the relationships between workers and that presidents and supervisors are more powerful than subordinates.

- The researcher believes that the existence of differences of statistical significance between the professor and both (assistant professor - teacher - teacher assistant - teacher) in the overall degree of their responses on the scale of organizational cynicism of faculty members and their assistants in favor of the teacher, but due to the nature of the problems and tasks entrusted to The members of the faculty support body, which vary from the degree of functional to the other and increases the lower the degree of functional such as:

- The workload associated with the division and the burden associated with the quality assurance unit

Thus, the answer to the fourth question of research, which states:

"What are the differences in the degree of organizational cynicism among faculty members and their assistants in the Faculty of Physical Education for Girls - Helwan University in view of the quality and accreditation according to the variable of functional grade (Professor Assistant Professor - Teacher - Assistant Lecturer Teacher)?"

\section{- Discuss the fifth question: -}

- The results of the study in the field of recognition of the relationship between management with high containment and organizational cynicism among faculty members and their assistants in the Faculty of Physical Education for Girls - Helwan University in light of quality and accreditation, as shown in Table (8) The Department of Higher Education in the Faculty of Physical Education for Girls and the dimensions of the measure of organizational cynicism among faculty members and their assistants in the Faculty of Physical Education for girls. There is also a statistical correlation between the total score of the management of high containment at the Faculty of Physical Education for Girls College degree scale organizational taunts at the faculty and their assistants at the Faculty of Physical Education for Girls members.

- The results of the present study are consistent with the results of the Hamid Salem study (2017). A statistically significant negative correlation was found between the perceived organizational, organizational and organizational support of the sample.

The results of the present study are consistent with the results of the Jayanthi, V., \& Anupama, R. -016 study. It was concluded that high containment management fosters professional self-esteem among staff, indirectly increases job satisfaction and provides Staff have the power and skills to make and effectively implement decisions.

- The results of the present study are consistent with the results of the study of both Lever and others (Olivier, D., 
et.al., 2015), where they found a statistically significant positive relationship between transformational leadership and high containment management.

The findings of the present study are consistent with the results of $\mathrm{Hu}$ and $\mathrm{B}$. (et.al.-2015). They found that there is a statistically significant positive correlation between human resources management practices and high containment management and the level of performance of the employees in the procurement department Years) working in the major companies of three industries (machinery industry - electronics industry - transport industry).

The results of the present study are consistent with the results of the HAYAT, K. \& ZAFAR, H, and 2016 studies. A statistically significant negative correlation was found between organizational cynicism and both political perceptions of the organization and perverse work behaviors in the workplace.

- The researcher believes that the reverse relationship between management containment and organizational cynicism is consistent with many results of scientific research, which found positive relationships between high containment management and many positive variables such as performance level (he and others -2015, Yang and Maine 2016), transformational leadership And 2015), and professional self-respect (Jayanthi and Anubama 2016), which means that high containment management as a positive variable has helped and supported many other positive variables as it is a positive supporter of the work environment.

- On the other hand, studies have found a link between organizational cynicism and some variables that have a negative impact on the work environment, such as deviant behavior behaviors (life of Wafar-2016), organizational silence (Karakaoglu -2015) and mismanagement by Ahmed Fathi (2015), And the violation of the psychological contract (Stankaya and Ozkara-2015), which means that organizational cynicism as one of the variables having a negative effect on the work environment arises and increases as a result of the increase or increase of the effect of some negative variables in the work environment.

Thus the answer to the fifth question of the research, which states:

"What is the relationship between management with high containment and organizational cynicism among faculty members and their assistants at the Faculty of Physical Education for Girls - Helwan University in light of quality and accreditation?"

\section{- Discuss the sixth question: -}

- The results of the study in the field of identification of the percentage of the administration's high containment in the organizational cynicism of faculty members and their assistants in the Faculty of Physical Education for Girls Helwan University in light of the quality and accreditation, as shown in tables $(9,10,11,12)(41.0 \%)$. The variables contributing from the administration to the high containment in the emotional satire came in the following (participation in decision-making) by $(43.8 \%)$, and the variables contributing from the management of high containment in behavioral cynicism came $(43.9 \%)$ followed by (training) and percentage (47.6\%). It was also found that there are two variables of management variables in high containment is the contribution to the degree of organizational cynicism among faculty members and their assistants at faculty Physical Education for Girls - Helwan University, where they can be arranged in descending order according to the percentage of their contribution as follows:

- The first variable is participation in making and making decisions with a contribution rate of $(44.8 \%)$.

- The second variable is (knowledge sharing) with a contribution rate of $(4.2 \%)$ to increase the percentage of management by high containment in the effectiveness of the degree of organizational cynicism to (49\%).

- The results of the present study are consistent with the results of the study of Türkus et al. (TÜRKÖZ, T., et.al.2013) where

They found that organizational cynicism could predict the organizational commitment of employees.

(Paveloni, A. \& Vîrgă, D., - 2013) - as the results of the present study agree with the results of the study of Kalman Paveloni and Veraja

They found that both organizational cynicism and moral intentions can largely predict job satisfaction and organizational citizenship behavior among employees of various government organizations in Romania (67\% of women)

- The researcher believes that the belief of faculty members and their assistants that the policies of college work lack the principles of justice, equality, transparency and credibility, and that such principles sacrificed in order to achieve the organizational benefits of the college, and this belief is formed by the recognition of contradictions and observations and analysis of different work experience college, Which gives a predictive indication of the degree of knowledge sharing and all the actions taken by the 
academic leadership in the faculty, which ensures the rapid circulation of knowledge among faculty members and their assistants, and the various units, committees, In order to carry out the work required to the fullest extent.

- The researcher believes that the contribution of both (participation in making and making decisions) and (knowledge sharing) has a contribution rate of (44.8\%) and $(4.2 \%)$ respectively. Is that participation in decisionmaking contributes significantly to the development of faculty members' sense that they are an integral part of the college community. They also increase their understanding of existing problems and their degree of responsiveness to the proposed solutions as they feel they have contributed to these solutions, Positive energy towards seeking the success of these solutions and proposals, which call for maximizing the role of participation Knowledge and to take all measures that ensure the speed of knowledge exchange between faculty members and their assistants, and the various units, committees and scientific and administrative departments of the college, with the appropriate quantity and quality, in order to take or participate in making the right decisions based on sufficient information and data from all units related to the problem. .

\section{Thus, the sixth question of the research was answered}

"What is the percentage of the administration's high containment in the organizational cynicism of faculty members and their assistants at the Faculty of Physical Education for Girls - Helwan University in light of quality and accreditation?"

\section{- Conclusions: -}

1- The value of the arithmetic average of the sample responses on the management scale by high containment at the Faculty of Physical Education for Girls - Helwan University in light of the quality and accreditation (from the point of view of the members of the Taris and their assistants) as a whole with a medium level of (115.86).

2 - The dimensions of the management scale can be arranged by high containment of the Faculty of Physical Education for Girls - Helwan University in light of the quality and accreditation (from the point of view of the members of the staff and their assistants) in descending order according to the value of the arithmetic mean as follows: (knowledge sharing - technological support participation in decision making - .

3- The class of the professor obtained the highest value of the arithmetic average in the management level by the high level of the Faculty of Physical Education for Girls -
Helwan University in light of the quality and accreditation (from the point of view of the members of the Board of Trustees and their assistants), reaching (152.20).

4 - There are differences of statistical significance between the professor and each of (assistant professor - teacher teacher assistant - teacher) in the overall score of their response on the scale of management high containment Faculty of Physical Education for Girls - Helwan University in the light of quality and accreditation (from the point of view of the members of the Board and their assistants) $\mathrm{Z}$, in favor of Professor.

5- The value of the mean of the sample responses on the scale of the organizational cynicism scale among faculty members and their assistants at the Faculty of Physical Education for Girls - Helwan University in light of the quality and accreditation (in their view) as a whole was higher than average (136.66).

6. The dimensions of the scale of the organizational syllabus can be arranged in the Faculty of Physical Education for Girls - Helwan University in light of the quality and accreditation (from their point of view) according to the value of the arithmetical average as follows (emotional scorn - cognitive scorn - behavioral scorn).

\section{- Recommendations:}

1. Amend the regulations and laws governing the conduct of university work in such a way as to ensure the participation of the members of the supporting body in the committees and the boards of the scientific departments of the college, and this can be done at least honorably, in order to ensure their participation and involvement in university work.

2 - The importance of involving members of the faculty and their assistants in their opinions in the formulation of policies governing the functioning of the faculty, and contribute to the development of the strategic plan of the College, and the formulation of the modernization of vision and mission.

3. Design and implement fair and firm accountability and accountability mechanisms that apply to all without exceptions due to the position factor, grade, age or level of experience.

\section{References:}

1- Abdel Hakim Ahmed, Islam Ali Abdulsalam (2016):

"The Relationship between Organizational Scorn and Social Alienation: An Empirical Study on a Sample of 
Faculty Members and Their Associates in Mansoura University", Egyptian Journal of Commercial Studies, Volume 40, Issue 2, P.

2 - Alsayd Ahmed Fathy (2015): "The role of mismanagement as a mediator in the affective relationship between functional cynicism and functional pressures - an applied study of Port Said Customs Sector", Journal of Financial and Commercial Research, Faculty of Commerce, Port Said University, Vol. 4).

3- Amer Ali Al-Atawi (2012): "Interpretation of organizational cynicism in organizations through the interconnection of the processes of psychological contract and internal respect: An analytical study of the views of a sample of workers in Al-Muthanna Cement Factory." Al Qadissiya Journal of Administrative and Economic Sciences, Volume 4, (2), p. (20).

4 - Amer Ali Al-Atawi (2016): "The nature and reasons of organizational cynicism among Iraqi employees - a field experimental study using scenarios.", Arab Journal of Administrative Sciences, Vol. 23, No. (2), p. (238).

5 - Ammar Fathy Mousa (2015): "The Role of Authentic Leadership as an Intermediate Variant in the Relationship between Evacuation of the Psychological Contract and Organizational Conspiciency - An Empirical Study", Journal of Financial and Commercial Research, Faculty of Commerce, Port Said University, No. (3), p.

6 - Anawi Rahio (2014): "The role of organizational justice in reducing the phenomenon of organizational cynicism - a field study on the members of the Faculty of Education University of Qadisiyah.", Muthanna Journal of Administrative and Economic Sciences, Volume (4), No. (10) .

7- Aslan, S. \& Eren, S.( 2014):"The effects of cynicism and organizational cynicismon Alienation ", The Clute Institute International Academic Conference,p.(620).

8- Aslam, U.,Ilyas, M.,Imran, M.,Rahman, U.,(2016):" Detrimental effects of cynicismon organizational change.",Journal of Organizational ChangeManagement, Vol.( 29), No.(4),p.(580-598).

9- BALAY, R.,KAYA, A.,CÜLHA, A.,(2013):" Relationship Between Organizational Culture and Organizational Cynicism ."Cumhuriyet Universitesi Journal of Economics \& Administrative Sciences (JEAS),Vol.( 14),No.(2), p.(123-144).

10- ÇETINKAYA, F.,ÖZKARA, B.,(2015):" PSYCHOLOGICAL CONTRACT BREACH AND ORGANIZATIONAL CYNICISM RELATIONSHIP IN
SERVICE BUSINESSES: A RESEARCH IN 4 AND 5

STARS HOTELS IN CAPPADOCIA

REGION.",Kastamonu University Journal of Economics \& Administrative Sciences,Faculty, Vol. (9), p.(72-91).

11- Dina Basem Kamal (2016): "The Effect of High Containment Management Practices in Activating Human Capital - A Case Study of Rafidain Bank in the Iraqi Capital Baghdad", Master Thesis, Middle East University, College of Business Administration, Jordan, p.

12- Doucet, O.,Lapalme, M.,Simard, G.,Tremblay, M.,(2015):"High involvement management practices as leadership enhancers.",International Journal of Manpower, Vol. (36),No.(7), p.(1060).

13- HAYAT, K.\&ZAFAR, H.,(2016):" Perception of politics and deviant workplace behavior, moderating impact of organizational cynicism in public sectorof Pakistan.",IAMURE International Journal of Business \& Management,Vol.( 12), p.(1-25).

14. Huo, B., Zhaojun, H., Haozhe, C. \& Xiande, Z. (2015):"The effect of highinvolvement human resource management practices on supply chainIntegration", International Journal of Physical Distribution \& Logistics Management, Vol.( 45) ,No.( 8), p.( 716 - 746).

15 - Hussein Falah, Abdullah Kazem Hassan (2010): "Management of high containment and its impact on organizational performance survey of the views of a sample of the employees of the General Company for Electrical Industries.", Journal of Qadisiya for Administrative and Economic Sciences, Volume (12), P. 22.

16- Hameed Salem Ghayad (2017): "The role of organizational support in reducing organizational cynicism - Analytical study of the views of a sample of training in the Faculty of Rafidain University", Journal of Administration and Economics, No. 111, p.

17 - Hind Abdel Fattah Ahmed Salem (2013): "psychological stress associated with the performance of faculty members in the faculties of physical education under the application of quality system.", $\mathrm{PhD}$ thesis, Department of Sports Management and Recreation, Faculty of Physical Education for Girls, Helwan University, .

18 - Islam Aly Abdel Salam (2016): "The relationship between organizational cynicism and alienation in work applied to faculty members and their assistants at Mansoura University.", Master Thesis, Department of Business Administration, Faculty of Commerce, Mansoura University, p. 
19- Jayanthi, V., \& Anupama, R. (2016): “Impact of High Involvement Work Practices on Employee's Attitude and Behaviour of Commercial Banks in Chennai", International Journal of Advanced Scientific Research \& Development,Vol.( 3), Special No.( 3), Version( I) ,p.(7).

20- Jialing, X.,(2016):"Contagion Effect of Organizational Cynicism on New Comers, and Employee's CWB.",Academy of Management Annual Journal, Vol. (20),No.(1), p.(1-16).

21- KARCIOĞLU, M. \& NAKTIYOK, A.,(2015): "THE ROLE OF THE PERCEIVED LEVEL OFCONFIDENCE ON CYNICISM IN ORGANIZATIONAL ENVIRONMENT: AN INVESTIGATION ON ATATURK UNIVERSITY

ADMINISTRATIVESTAFF.",Journal of Economics \& Administrative Sciences, Üniversitesi Iktisadi ve Idari Bilimler Fakültesi Dergisi,Vol. (17),No.( 1), p.(19-34).

22- KARACAOĞLU, K., Cengiz,K.,(2015):" The Effect of Employee Silence on Organizational Cynicism: A Study on Public Employees.",Ege Academic Review, Vol. (15), No.( 3), p.(401-408).

23- KARACAOĞLU, K.\&INCE, G.,(2013):"THE EFFECTS OF POSITIVE ORGANIZATIONAL BEHAVIOR ON ORGANIZATIONAL CYNICISM: A CASE STUDY KAYSERIS MANUFACTURING INDUSTRY.",Suleyman Demirel University Journal of Faculty of Economics \& Administrative Sciences,Vol.( 18),No.(1), p.(181- 202).

24- KESEN, M.\& AKYÜZ, B.,(2016):"The Investigation of the Relationships amongAcademic Self- Efficacy Perception, Organizational Trust and Organizational Cynicism via Structural Equation Modeling: An Application on University Students.", Cumhuriyet Universitesi Journal of Economics\& Administrative Sciences (JEAS), Vol. (17), Issue (1), p(265-286).

25- KILIÇ, R.,(2015):" A RESEARCH ON THE RELATIONSHIP BETWEEN THE EMOTIONAL INTELLIGENCE AND PERCEPTION OF ORGANIZATIONAL CYNICISM OF EMPLOYEES.",Journal of Management \& Economics Research, Vol. (13),No.(2), p.(59-73).

26- Nawal Nasr (2017): "An Analytical Study of the Relationship between High Containment Management and Developing Administrative Creativity for School Personnel", Journal of the Egyptian Association for Comparative Education and Educational Management, 24th Annual Conference, pp. 382, 383.
27- Olivier, D., Lapalme, M., Simard, G \& Tremblay, M. (2015):" High involvement management practices as leadership enhancers. International Journal of Manpower", Vol.( 36) ,No.( 7), p.( 1058 - 1071).

28 - Osama Ahmed Hassanein (2013): "Burning the psychological contract and the perceptions of political behavior as a determinant between organizational cynicism and its relation to anti-productive work behaviors - field study", Journal of Contemporary Business Research, Faculty of Commerce, Sohag University, No. (1) ), Pp. 73-111.

29- Paveloni, A.,\&Vîrgă, D.,(2013):"The impact of cynicism and ethical intentions on organizational attitudes: work engagement, job satisfaction and organizational citizenship behavior.",Human Resources Psychology,Vol.( 11),No.( 2), p.(28-44).

30- Safaa Saadoun, Yasmeen Kassem (2017): "The Relationship between Organizational Scorn and the Commitment of the Employees - An Analytical Study of the Attitudes of the Civil Defense Directorate" Karbala ", Journal of the Faculty of Safwa University, Vol. (3) $(6,7)$.

31-Sanaa Mustafa Mohamed (2016): "The Relationship of Management to Higher Containment in Enhancing Administrative Creativity - A Field Study Applied to Assiut Oil Refining Company", Arab Journal of Management, Volume 36, No. (1), p. (282).

32- Sanoubar, N.\& Bajestani, M.,(2015):" Organizational Change Cynicism: Does It Hinder Change Commitment", Change Management: An International Journal, Vol.( 15) ,No.(2), p.(19-33).

33- Scott, K.\& Zweig, D.,(2016):"Organizational Cynicism and LMX in Dyads:Implications forEngagement, Self-Efficacy and Performance.", Academy of Management Annual Meeting Proceedings, Vol.( 2016), No.( 1), p.(1-11).

34- Sheel, R.\&Vohra, N.,(2016 ):" Relationship between perceptions of corporate social responsibility and organizational cynicism: the role of employee volunteering.",International Journal of Human Resource Management, Vol. (27),No.( 13), p.(1373-1392).

35- TÜRKÖZ, T.,POLAT, M.,COȚAR, S.,(2013):"The Role of Employees' OrganizationalTrust and Cynicism Perceptions on Organizational Commitment.", Journal of Management \& Economics, Vol. (20), No.( 2), p.(285302).

36- Wood, S., Van Veldhoven, M., Croon, M., De Menezes, L. (2012):" Enriched jobdesign, high 
involvement management and organizational performance: The mediating roles of job satisfaction and well-being.", Human

Relations Journal, Vol.( 65),No.( 4), p.( 420).

37- Wood, S.,Burridge, M.,Rudloff, D.,Green, W.,Nolte, S.,(2015):" Dimensions andlocation of high-involvement management: fresh evidence from the UKCommission's 2011 Employer Skills Survey.", Human Resource Management Journal, Vol.( 25),No.( 2), p.(166- 183).

38- Ying, Z.\&Min, Z.,(2016):"The Effect of High Involvement Management on Employee Well-Being in Britain.",Academy of Management Journal , Vol.(1) ,No.(1), p.(1-11). 